\title{
Transmission and spread of STIs and RTIs among Youths' in Higher Learning Institutions and Neighbors Villages in Mbeya City, Tanzania
}

\author{
Dr Kibani L. H, Mr Matem A. \& Dr Mwangosi F \\ Mbeya University of Science and Technology, Department of Technical Education
}

P.O Box 131 Mbeya City, Tanzania

\begin{abstract}
Sexually Transmitted Infections (STIs) are diseases often spread from person to person through sexual contact. The infections cause sexually transmitted diseases and Reproductive Tract Infections (RTIs). It has been well established that risk sexual behaviors among youths significantly influences their reproductive and general health. This study therefore investigated on the spread and transmission of sexual transmitted and reproductive tract infections to three Higher Learning Institutions (HLIs) and Neighbor Village Youths (NVYs) in Mbeya district Tanzania. The study aimed at identifying the social interaction, sexual behaviors, knowledge on impact of sexual transmitted infections, influence of physical environment and future plan of HLIs and NVYs. The study was guided by two theories, social learning theory in particular 'Social Psychology Theory' and the 'Theory of Possible Selves'. The study included 210 HLIs and 100 NVYs all aged between 1830 years. Youths were randomly sampled from their areas. Data collection methods included survey questionnaires, focus group discussion and documentary review. The study employed a random sampling procedure. A cross-sectional research design was adopted. Thematic and descriptive statistical analysis were employed. The results were as follows: Social interaction among youths of both sides, higher learning institutions and neighbor villages has negative impact since it creates vulnerability to STIs/RTIs/HIV infections. Youths were found engaging much in risk social behaviors which in turn lead them to reproductive complications such as abortions, PID, unplanned pregnancies, single parent childcare, academic dropout, poor academic achievement and the whole issue of personal and public underdevelopment socially, healthily and mentally. Results shows that youths lack clear knowledge about STIs and RTIs but were familiar with HIV/AIDS however, they were fearing of getting pregnancies rather than infections. Village youths' future plans were about getting money and become rich person while higher learning institutions youths planned to get employment after graduating, to get nice houses and becoming somebody. In general risky sexual behaviors such as love affairs, unprotected sexes, multiple partners, luxurious lives, lack of knowledge, poverty, homeless, poor socio-economic status, low income, inherited western cultures and poor use of mobile networking among youths found as key contributors of spread and transmission of STIs/RTIs and HIV/AIDS in Mbeya district. The study recommend for collaborative effort between varied stakeholders in educating and giving supportive services to youths to improve their health and wellbeing.
\end{abstract}

Key words: Sexual Transmitted Infections, Reproductive Tract Infections, Youths, HIV/AIDS

\section{INTRODUCTION}

Sexual transmitted infections are not only HIV/AIDS but Some of the more other common sexual resulted infections include Gonorrhea, hepatitis, chancroid, Human Immunodeficiency Virus (HIV), genital helpers, Human papilloma virus (HPV or genital warts, syphilis and Trichomoniasis (Kristin; Rena; Claire; Brindis, \& Philip, 2011). According to these authors, STIs are caused by germs that live on the skin or in the body fluids like semen, vaginal fluid or blood. Recent studies have shown that STIs results to RTIs and currently there is more spread and transmission of the mentioned infectious diseases especially to young people of age between 15-25 years than to adults (Kristin et al. 2011; World Health Organization (WHO) 2016 \& Chalamilla; Mbwana; Mhalu; Mmari; Majigo; Swai; Urassa, and Sandstrom, 2016; Abdul et al. 2018).

In this study youths are regarded as young people aged from 18 to 30 years. At this particular age group youths are said to be sexually active and health-damaging sexual behaviours start during that period (Wekesh; Nyakangi; Njagi \& Bangha, 2019). Youths through sexual experimentation and seeking of marriage opportunities in most cases lead them into risky health and sexual behaviours. Sexual behaviours among youths has been a focus of health programs worldwide since the International Conference on Population and Development (ICPD) in 1994 (WHO, 2016). According the Ministry of Health and Social Welfare (2018) in Tanzania sexually transmitted infections especially Chlamydia, Gonorrhea, Syphilis, Hepers and HIV/AIDS are highly found to male and female aged below 24 years. There are more than 30 types of bacteria, viruses, or parasites that cause STIs (WHO/UNAIDS, 2021)

Yet sexual transmitted infections such as STIs, RTIs and HIV/AIDS were reported to be vulnerable to youths of mentioned ages. Reproductive complications, unplanned pregnancies and single parent children have been associated outcomes of youths sexually behaviours which endanger their lives. Youths living in higher learning institutions and neighbor villages are at higher risk of engaging in sexual transmitted infections because of unsafe interactions, love affairs and indiscipline sexual behaviours. Accordingly, this 
study explored on the transmission and spread of sexual transmitted infections in particular STIs, RTIs and HIV/AIDS in higher learning institutions and neighbor villages in Mbeya district Tanzania.

\section{BACKGROUND}

Youths decisions in the issues of relationship and sexuality behaviours reported to impact their wellbeing including health and academic performances. Different nations have been engaging in protecting their youths on the issue of sexual transmitted infections. Hong-Kong for instance integrated sexual education in their schools and in 1997 they introduced guidelines on sexual education (Fenton; Johnson; McManus $\&$ Erens. 2021). Cheng, (2018) outlined the experience of sexuality education in different countries. For instance, he noticed that in Singapore, sexuality education is compulsory for all schools and since 2000 the Ministry of Education allowed implementation of sexual education guidelines to all levels of education. School curriculum in Singapore involve themes such as 'Human development, interpersonal relationships, sexual health, sexual behaviours, culture, society and law. All these themes aims at giving youth education which can help them to escape from risk sexual infections. In Taiwani, Cheng informed that it is required by law to conduct sexuality education including gender equity education, child and youths sexual exploitation. Cheng further pointed that youths because of lacking education they fail to protect themselves against coercive and abusive sexual activities, unintended pregnancies and STIs such as HIV/AIDS and associate RTIs. The author added that sexually behaviours and reproductive health among youths is not promising since often they are engaging in risk sexuality acts and they have no experience of checking up their health for STIs. In Sub-Saharan Africa, (Madeni; Horiuchi \& Lida, 2011) established that various countries in Africa face the problems of youths engagement in early sexual intercourse. Sub-Saharan Africa was found to be among other African countries where $10 \%$ of girls become mothers by the age of 15 years old. Similarly, Chalamilla, (2016) in Tanzania found that the problem of teenage pregnancies to school girls is critical and HIV infections were observed to young people to large extent in some regions.

More recent studies driven largely by public health responses on STIs, dealt much with issues of HIV/AIDS and PVC than other infectious like Gonorrhea, Syphilis, Chlamydia, Herpers which today are spreading faster to those playing unprotected sexual acts. Fenton et al. (2021) noticed that the key areas of inquiry about STIs transmission in various Sub-Saharan countries including Tanzania has been on describing symptoms of the infections and giving statistical data of people infected with HIV/AIDS regional wise without take much concern on other STIs and how fast spread among people and its impact to their lives. Knowing of how much people are infected with HIV/AIDS without exploring on sexual behaviours in association with the rate of spread and transmission may slow the prevention measures and therefore negative impacts may increase silently. Fenton et al. (2021) established that it is imperative to understand on how epidermis of STIs or HIV are generated and therefore informing disease control strategies.

Various epidemiological research on HIV/STIs have found that the high rate of spread and transmission is through sexual intercourse. People who engage in unprotected sexual intercourse and associated behaviours are mostly likely to get infections. Members with more than one partner are the key agent of spread of STIs infections (Fenton et al. 2021). More researches contended that STIs transmission dynamics showed prevalence's to young people than adults and more vulnerable to females than males (Madeni; Horiuchi \& Lida, 2011). These germs can enter the body through the vagina, mouth, anus, and open sores or cuts. Some germs, like the ones that cause herpes or genital warts, infect a person through the skin of the genitals. The germs pass from an infected person through contact with skin, blood, or body fluids. Sexual contact (oral, vaginal, anal) with an infected person is the most common way to become infected. The issue of relationships and sexuality among youths is of paramount to consider. WHO/UNAIDS (2021) similarly found that there is a growing recognition of high degree of morbidity and mortality rate caused by STDs and HIV infections. STIs/RTIs infections reported to be a global pandemic problem especially to women (WHO, 2016) yet paucity studies have dealt with sexual transmitted infections to youths in higher learning institutions. This study investigated on the transmission and spread of STIs/RTIs and HIV/AIDS among youth and their experienced sexual behaviours.

\section{Statement of the Problem}

The national initiatives to improve adolescent and youths' health has been focusing much on HIV/AIDS with little attention on other STIs and resulted RTIs (Madeni; Horiuchi \& Lida, 2011). Paucity studies examined the issues of STIs and RTIs to higher learning institutions youths as in this study. Closely related studies such as those of Chalamilla et al., (2016) and WHO/UNAIDS, (2021) discussed on the STIs and STDs to adolescents and youths in general but not to higher learning institutions. However these studies noticed that there is a growing spread of STIs and HIV infections to youths of 15-25 years of age than those above that age. The impact of STIs to youths include death, reproductive tract infections, unplanned pregnancies, sterility and more other health problems.

Basing on such situation this study investigated on the transmission and spread of STIs, RTIs and HIV/AIDS among higher learning institutions and neighbor village youths. The aim was to identify social interaction characteristic, sexual behaviors, knowledge on impact of sexual transmitted infections and future plan of higher learning institutions and neighbor village in Mbeya district and thereafter recommend on the way forward. 


\section{Purpose}

Therefore, this study aims to investigate on the transmission and spread of STIs, RTIs and HIV/AIDS among youths' in higher learning institutions and neighbor villages in Mbeya district.

\section{Objectives}

1. To assess sexual behaviors and associated factors among youths in higher learning institutions and neighbor villages.

2. To investigate on the social interaction, youth's knowledge on impact of STIs and youths future plan of their lives as shared by both higher learning institutions and neighbor village youths in Mbeya district.

\section{Theoretical Framework}

The study was guided by two theories namely Social psychology theory and theory of possible selves. Social psychology theory also called social interaction theory stresses on examining the patterns of actions and reactions in response to other people. In this study, youths sexual behaviours directly reflect their knowledge and understanding of STIs, RTIs and HIV/AIDS and social expectations of their future. Sexual behavior of youths describe the patterns of how they interact with each other, their peers, friends and social roles in the area they lives. Youths in higher learning institutions the way they interact with village youths socially can be defined from the outcome assessed on their responses. The theory of possible-selves describes how future oriented thought provides identity relevant information and motivation to pursue self-relevant goals (Gesselin et al. 2010). According to these authors, possible-selves theory is used to understand identity of new members in a study.

In this study the theory helped to study youth's social interaction basing on sexual behaviours especially on decisions they made on love affairs, selection of partners, their expectations and level of understanding. According to these theories the influence range of social interaction and social behaviours has implications on youth's health, educational outcomes and their future plan. According to Markus \& Nurious (1986) possible-selves theory stresses that the role of social interaction and around social contexts contribute in identity development of a person. Further, the potential influence of the physical environment of people, for this case youths is active contributor of their identity and future plan. In this study, place based experiences as a HLIs or NVY thought to determine on what they plan for their future lives while engaging in risk sexual characteristics. The role of physical environment of youths and what they demonstrate in one way or another may contribute to spread and transmission of STIs and RTIs.

\section{METHODOLOGY}

The study was conducted in three higher learning institutions and three villages around those universities in Mbeya City
District. A total of 210 university students and 100 village youths all aged between 19-30 years were randomly sampled for the study. Data collection methods included survey questionnaires, focus group discussion and documentary review. Sampling techniques included a random sampling procedure. A cross-sectional research design was adopted. Thematic and descriptive statistical analysis were employed.

\section{RESULTS}

\section{Demographic Information}

Table 1: Respondents Status

\begin{tabular}{|c|c|c|}
\hline \multirow{2}{*}{$\begin{array}{c}\text { Youths } \\
\text { Residence }\end{array}$} & \multicolumn{2}{|c|}{ Sex } \\
\cline { 2 - 3 } & Male & Female \\
\hline Village youths & 50 & 50 \\
\hline $\begin{array}{c}\text { University } \\
\text { youths }\end{array}$ & 105 & 105 \\
\hline Total & 155 & 155 \\
\hline Overall Total & \multicolumn{2}{|c|}{310} \\
\hline
\end{tabular}

Source: Field Data

Results in Table 1 shows that village youths were few in numbers (100) compared to university students who were (210) however, gender equality was considered in both cases. That is, both male and female participation was regarded equally.

Table 2: Respondents Age Group

\begin{tabular}{|c|c|c|c|c|}
\hline \multirow{2}{*}{$\begin{array}{c}\text { Age Group } \\
\text { (Years) }\end{array}$} & \multicolumn{2}{|c|}{ Village Youths } & \multicolumn{2}{c|}{ University Youths } \\
\cline { 2 - 5 } & Male & Female & Male & Female \\
\hline $18-20$ & 13 & 19 & 08 & 11 \\
\hline $21-23$ & 10 & 12 & 19 & 25 \\
\hline $24-26$ & 14 & 12 & 33 & 48 \\
\hline $27-29$ & 09 & 05 & 39 & 21 \\
\hline $30<$ & 04 & 02 & 06 & 00 \\
\hline Total & $\mathbf{5 0}$ & $\mathbf{5 0}$ & $\mathbf{1 0 5}$ & $\mathbf{1 0 5}$ \\
\hline $\begin{array}{c}\text { Overall } \\
\text { Total }\end{array}$ & \multicolumn{3}{|c}{$\mathbf{3 1 0}$} \\
\hline
\end{tabular}

Results in Table 2 shows that respondents in this study majority were village youths who falls under18-20 and 24-26 years male and university youths fall under 24-26 and 27-29 years for both male and female.

Table 3: Respondents' Marital Status

\begin{tabular}{|c|c|c|}
\hline \multirow{2}{*}{ Respondents } & \multicolumn{2}{|c|}{ Married } \\
\cline { 2 - 3 } & Male & Female \\
\hline Village Youths & $33=66 \%$ & $41=82 \%$ \\
\hline University Youths & $28=26.7 \%$ & $35=33.3 \%$ \\
\hline
\end{tabular}

Results in Table 3, shows that both NVY male and female were married than those in HLIs. Moreover, females in villages' majority $82 \%$ are married if compared to $33 \%$ HLIs females. During the focus group discussion village female youths noticed that they had more than one university 
boyfriends and they engaged in sexual activities. Some female village youths complained of having misunderstanding with village males because of love affairs with university males,

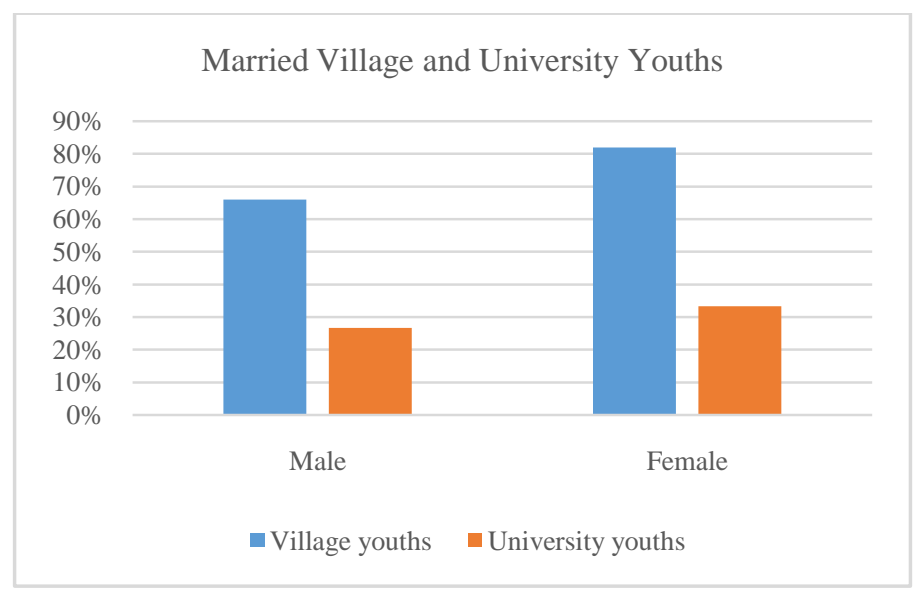

Fig. 1 Marriage Status among Youths

Results in Fig. 1 show that majority almost $69 \%$ village youths male and $80 \%$ female are married compared to university youths where only $27 \%$ male and $34 \%$ female are married. In other words many youths in the village are engaging much in sexual activities.

Findings from the focus group discussion on the same aspect had the following responses. Youths when asked on their marital status they said that, they are married but they live single. Some youths had children, some said they divorced, where some said they had never marry but they have children. These responses meant that the results in Fig. 1 above doesn't means that married youths stay together as wife and husband instead some had sexual partners.

The results showed that youths aged between 19-30 years engaged much in love affairs with integrated modern cultures but limited understanding on possible risk outcomes. Findings showed that $82 \%$ females and $23 \%$ male infected with Chlamydia and Gonorrhoea but did not showed symptoms. $71 \%$ youths aged 19-26 found more infected with STIs/RTIs/HIV than 54\% who were 27-30 years. Majority $83 \%$ village youths and $73 \%$ university students had limited knowledge on STIs/RTIs infections. Villages around universities had more young females with single parent children who's further were unknown university students. Village male youths were in conflict with university male students because of love affairs with females. Also from January-June 2021, students with Gonorrhea in institution 'A' were $5 \%$ male and $3 \%$ female; Institution ' $\mathrm{B}$ ' $7 \%$ male and $4 \%$ female; Institution ' $\mathrm{C}$ ' were $5 \%$ male and $4 \%$ female. The overall knowledge regarding STIs, RTIs and HIV/AIDS is limited among youths although female with young children had some information on sexual transmitted infections. It was because of attending pre-natal clinic.

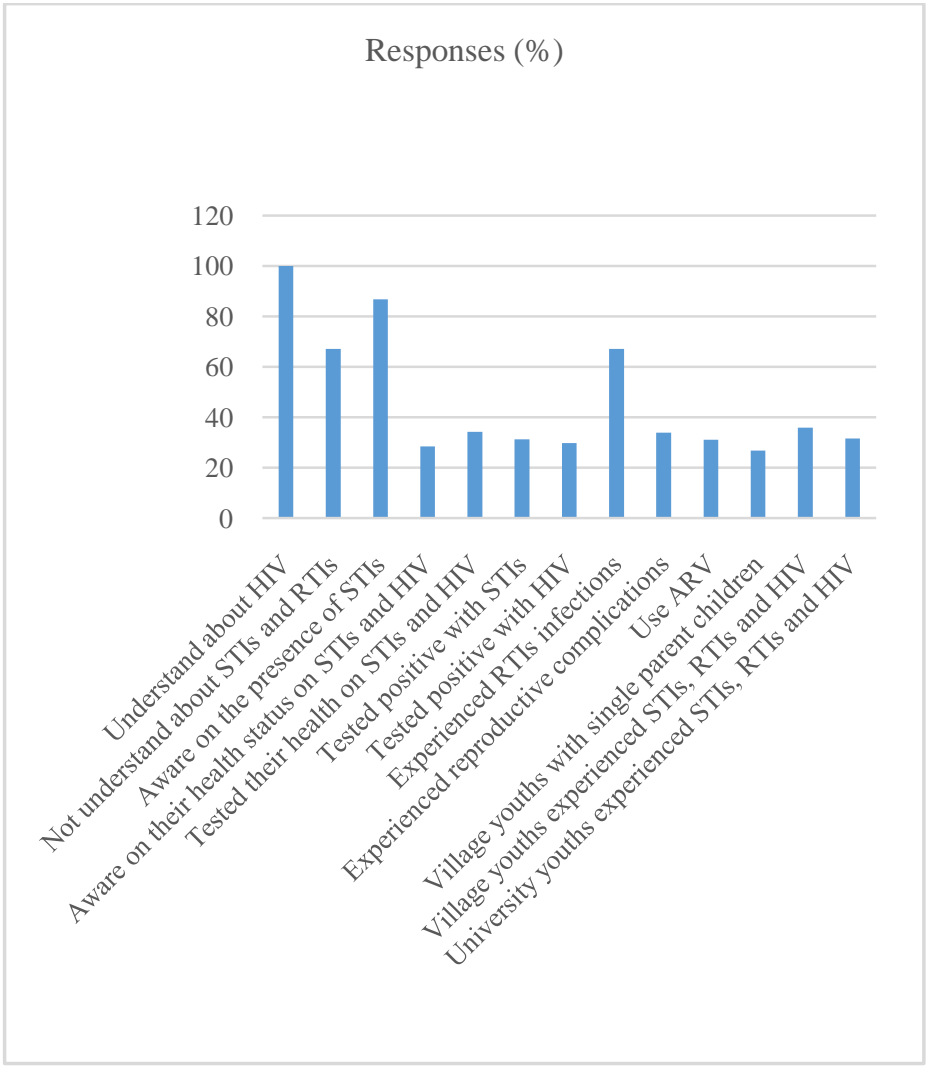

Fig. 2

The results of this current study have shown that all youths $(100 \%)$ were aware on HIV and $86.8 \%$ on STIs infections but $67.1 \%$ did not understand on STIs and RTIs spread and outcomes. $35.2 \%$ village youths in particular female experience RTIs infections and reproductive complications. $31.6 \%$ university youths experienced STIs, RTIs and HIV infections as can be seen in figure in 1

\section{University and Village Youths Experienced Sexually Transmitted Infections}

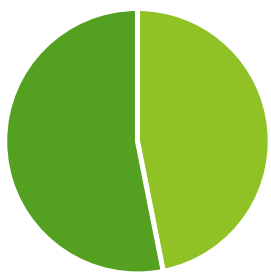

\footnotetext{
- University youths experienced STIs, RTIs and HIV infections

- Village youths experenced STIs, RTIs and HIV infections
}

Figure 3

Results in Fig. 3 shows that village youths (35.8\%) were more infected with STIs, RTIs and HIV infections than university youths $(35.2 \%)$ however, though focus group discussion young female in the nearby villages agreed to have more than three partners who are university students. This means than 
can be more infected university students than the shown figure above. Findings also indicates that university and nearby village youths' engage in sexually relationships. The results in Table one below show the reality.

Table 4: Sexually Behaviour among Village and University Youths

\begin{tabular}{|c|c|c|c|c|c|c|c|c|c|}
\hline \multirow{4}{*}{$\begin{array}{l}\mathbf{S} / \\
\mathbf{N}\end{array}$} & \multicolumn{5}{|c|}{$\begin{array}{c}\text { Village youths }(\mathrm{N}=100) \\
\text { Male }=50 \\
\text { Female }=50 \\
\end{array}$} & \multirow{2}{*}{\multicolumn{4}{|c|}{$\begin{array}{c}\begin{array}{c}\text { University youths }(\mathrm{N}=210) \\
\text { Female=105 }\end{array} \\
\text { Responses }\end{array}$}} \\
\hline & \multirow{3}{*}{ Statements } & \multicolumn{4}{|c|}{ Responses } & & & & \\
\hline & & Agree (F) & $\begin{array}{c}\text { Disagree } \\
(\mathbf{F})\end{array}$ & $\begin{array}{c}\text { Agree } \\
\text { (F) }\end{array}$ & $\begin{array}{c}\text { Disagree } \\
(\mathbf{F})\end{array}$ & $\begin{array}{c}\text { Agree } \\
(\mathbf{F})\end{array}$ & $\begin{array}{l}\text { Disagr } \\
\text { ee }(\mathbf{F})\end{array}$ & Agree (F) & $\begin{array}{c}\text { Disagre } \\
\text { e (F) }\end{array}$ \\
\hline & & Male & Male & Female & Female & Male & Male & Female & Female \\
\hline 1. & Have University partner & 18 & 32 & 42 & 08 & 97 & 08 & 87 & 18 \\
\hline 2. & $\begin{array}{l}\text { Have a child/children } \\
\text { with university student }\end{array}$ & 05 & 45 & 31 & 19 & 05 & 100 & 04 & 101 \\
\hline 3. & $\begin{array}{c}\text { Have non-university } \\
\text { partner }\end{array}$ & 13 & 37 & 14 & 36 & 58 & 47 & 22 & 83 \\
\hline 4. & $\begin{array}{l}\text { Have more than one } \\
\text { partner }\end{array}$ & 21 & 29 & 39 & 11 & 79 & 26 & 98 & 07 \\
\hline 5. & Have village partner & 04 & 46 & 25 & 25 & 88 & 17 & 13 & 92 \\
\hline 6. & $\begin{array}{l}\text { Have more than one } \\
\text { village partner }\end{array}$ & 07 & 33 & 17 & 33 & 41 & 64 & 11 & 94 \\
\hline 7. & $\begin{array}{l}\text { Have both village and } \\
\text { university partner }\end{array}$ & 06 & 44 & 40 & 10 & 59 & 46 & 34 & 71 \\
\hline 8. & $\begin{array}{l}\text { Have a child/children } \\
\text { with village partner }\end{array}$ & 34 & 16 & 39 & 11 & 62 & 69 & 60 & 45 \\
\hline
\end{tabular}

Source: Field data

Table 4 shows experienced sexually behavior among village and university youths. It is evident that more village females near to university (31) out of (50) had children with university males. But more village male 37 had non-university partners while more university male (97) had village female partners than university female students. The life style between youths in these two areas allow circulation of spread of STIs, RTIs and HIV infections. The circulation is in the same box. Further exploration revealed that high proportions of youths practice sexual intercourse.

Table 5: The overall findings were as follows:

\begin{tabular}{|c|c|c|c|}
\hline & Statements & Higher learning institutions youths & Nighbour village youths \\
\hline 1. & $\begin{array}{l}\text { Social interactions related to } \\
\text { sexual issues }\end{array}$ & \begin{tabular}{|} 
More interactions were of HLIs male with \\
village females. \\
HLIs female with their partners from \\
different HLIs. Village males with few HLIs \\
females
\end{tabular} & $\begin{array}{l}\text { - More female with HLIs males. } \\
\text { Village males interact with females from far } \\
\text { villages but with minimal HLIs females. }\end{array}$ \\
\hline 2. & $\begin{array}{l}\text { Social behaviors related to sexual } \\
\text { activities }\end{array}$ & $\begin{array}{l}\text { Demonstrated behaviours included: Love } \\
\text { affairs, conflicts especially to males of both } \\
\text { sides, elegances and sexual intercourse. }\end{array}$ & $\begin{array}{l}\text { Love affairs, competition between village } \\
\text { males with HLIs males. } \\
\text { Love affairs conflict between HLIs females } \\
\text { and village females. }\end{array}$ \\
\hline 3. & $\begin{array}{l}\text { Knowledge on impacts of STIs, } \\
\text { RTIs, HIV/AIDS }\end{array}$ & $\begin{array}{l}\text { In general majority } 89.1 \% \text { had knowledge on } \\
\text { HIV/AIDS and a bit on STIs. } \\
51.9 \% \text { seemed to fear of STIs but they didn't } \\
\text { think of getting infections through bared } \\
\text { sexual intercourse, } \\
53.8 \% \text { said they had never checked their } \\
\text { health for HIV/AIDS and } 78.1 \% \text { said they } \\
\text { never go for checkup of their health in } \\
\text { particular STIs. }\end{array}$ & $\begin{array}{l}\text { 35\% female were familiar with HIV/AIDS } \\
\text { and some of STIs. } \\
\text { - Female were able to explain on the } \\
\text { reproductive tract infections. } \\
\text { It was because of experience and attending } \\
\text { of pre-natal clinics. }\end{array}$ \\
\hline & 4. Future plan & $\begin{array}{l}\text { Majority } 68.1 \% \text { planned to complete their } \\
\text { studies and get employment. } \\
\text { On outcome of their sexual intercourse with } \\
\text { partners, few } 9.5 \% \text { said that they expected to } \\
\text { marry their girlfriends/boyfriends after } \\
\text { graduating. } \\
\text { Others } 48.1 \% \text { said that the relationship they } \\
\text { had was for companying each other. } \\
37.7 \% \text { said that love affairs to youths is a }\end{array}$ & $\begin{array}{l}\text { 69\% planned to have large business and get } \\
\text { cars and houses. } \\
\text { 33\% female said that they prefer to have } \\
\text { sexual partners from higher learning } \\
\text { institutions because of various reasons } \\
\text { including: getting some money, getting } \\
\text { educated boyfriends, looking for fiancés and } \\
\text { husband and just loves. } \\
\text { On the issue of future plan 59\% male said }\end{array}$ \\
\hline
\end{tabular}




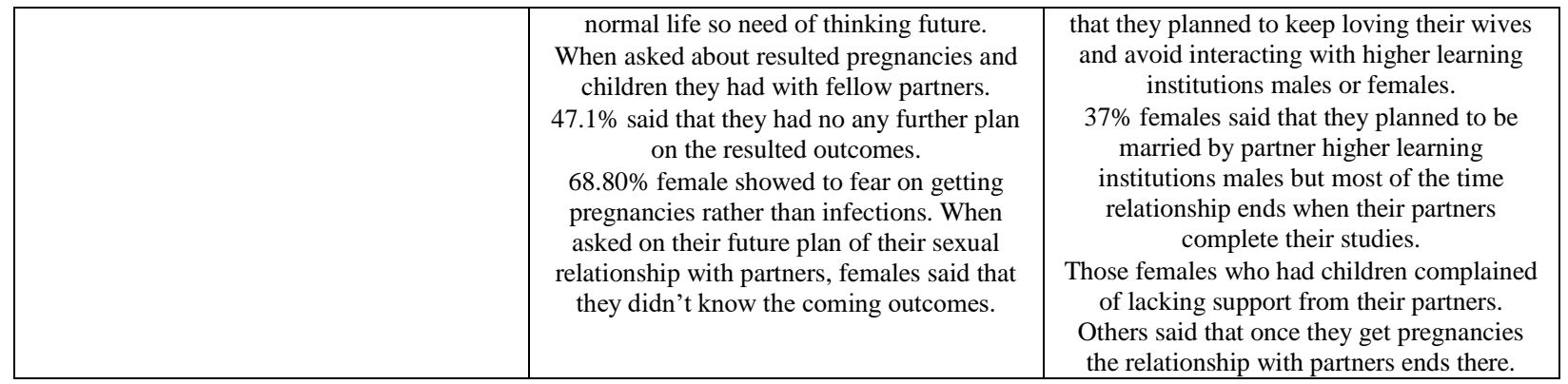

Source: Field Data

Results in the Table 5 show that youths are engaging in risky sexual behaviours as an attainment and leisure's without

thinking of presence of STIs, RTIs and HIV/AIDS which resulted as outcomes.

Table 6: Sexual behaviours reflecting to spread and transmission of STIs, RTIs, HIV/AIDS

\begin{tabular}{|c|c|c|c|c|c|c|}
\hline Sexual behaviours & & $\begin{array}{c}\text { Applied } \\
\text { frequently }\end{array}$ & & $\begin{array}{c}\text { Applied } \\
\text { occasionally }\end{array}$ & $\begin{array}{c}\text { Never } \\
\text { applies }\end{array}$ & \\
\hline & Male $(\mathrm{N}=155)$ & Female $(\mathrm{N}=155)$ & Male & Female & Male & Female \\
\hline $\begin{array}{l}\text { Sexual partner/ } \\
\text { friendship }\end{array}$ & 108 & 96 & 17 & 10 & 1 & - \\
\hline Sexual intercourse & 71 & 83 & 63 & 56 & 21 & 16 \\
\hline Oral sex & 45 & 60 & 43 & 71 & - & 2 \\
\hline Hugging & 118 & 102 & 33 & 53 & - & - \\
\hline Anal sex & - & - & 3 & 2 & 152 & 153 \\
\hline Kissing & 134 & 149 & 21 & 06 & - & -52 \\
\hline Attend night club & 87 & 104 & 52 & 43 & 16 & 08 \\
\hline Peer influence & 32 & 11 & 69 & 78 & 54 & 66 \\
\hline Take alcohol & 95 & 77 & 52 & 44 & 8 & 34 \\
\hline Visit prostitute & 1 & - & 39 & 04 & 115 & 151 \\
\hline Use cigarette/drug & 39 & 4 & 49 & 66 & 68 & 85 \\
\hline
\end{tabular}

Source: Field Data

Findings in Table 6 in general reveals that youths still play sexual activities frequently and without taking care on spread and transmission of STIs, RTIs, HIV/AIDS. When asked during the focus group discuss in majority $70 \%$ engage in unprotected sexual intercourse and do not attend health checkup clinic. When they got infections they said that they feel shame to go for treatment until when it becomes serious otherwise they buy antibiotic from pharmacies and treat themselves.

\section{DISCUSSION}

Based on theoretical perspectives, findings in this study revealed that place-based experience of youths in relation to social interaction, sexual behavours, knowledge and understanding influence present development of future plans of youths which has implication to the spread and transmission of STIs//RTIs, HIV/AIDS infections. Findings from documents in particular Deans' offices indicates that, youths staying outside campus of their learning institutions had more cases of love affairs conflicts, suicide because of love issues, pregnancies, abortions, reproductive complications, unplanned children and disciplinary cases and problems associated with performances in university examinations like supplementary than those staying in hostels.

Off-campus HLIs youths face many challenges which put them in temptations of engaging in love affairs with village people's wives or husband. The place off-campus youths lives, their interaction with local people has contribute them to share sexual behavours such as smokes, sexual intercourse, oral sexes, sharing of sharp objects in particular shelving, bathrooms and toilet materials. Some local people and youths themselves have low level of knowledge about STIs, HIV/AIDS and resulted RTIs hence they relax and interact friendly with no health care. Young ladies in local areas around learning institutions feel proud to have sexes with university guys without thinking of presence of STIs. When asked during the focus group discussion majority fear pregnancies but not infections. This study found that the situation is cumbersome since NVY especially females had many children with no father support, others practice abortion, others said they plant stick for five years and hence they are free to play sex. Other females said that their sexual partner 
don't like them to use condom and therefore they play sex bared.

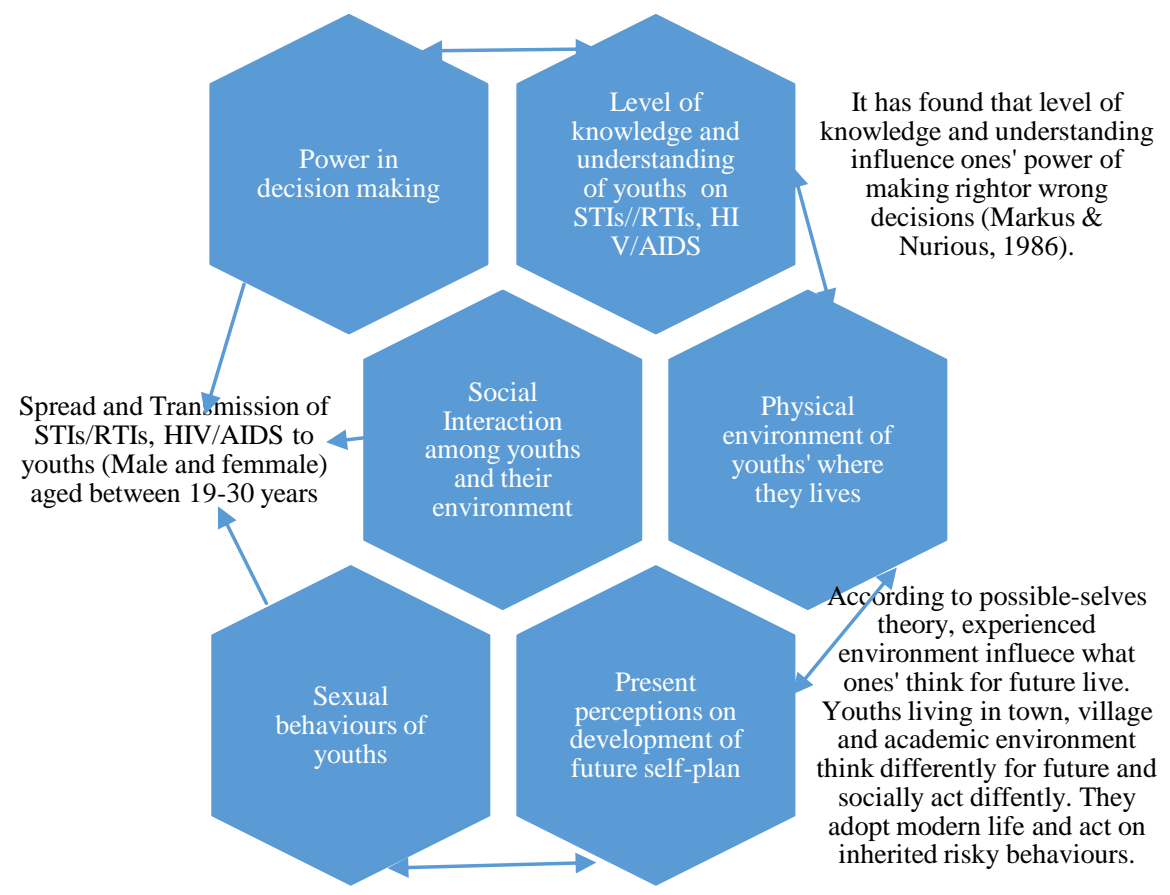

Fig. 4 Theoretical Framework on the Spread and Transmission of STIs/RTIs, HIV//AIDS

Physical environment where youths live influence their decision making of the issue of relationships and sexuality characteristics. Youths especially female make inappropriate decisions on sexual intercourse as majority said that their partner refuse to use condoms. The implication to lack of power of deciding on rights of their body impacts on their health and well-being for the issues of sexual relationships. Youths' knowledge and skills about their sexual and social relationship has influence on the ability to protect themselves against abusive sexual activities, unintended pregnancies and STIs, RTIs, HIV/AIDS. Sexual behaviours of youths aged between 19-30 most of the time involve luxurious life, selfdecisions, entaterinment, active in sex acts which all together impact on their reproductive health's'. All blocks recycle the social interaction. This is because every aspect result through interaction among youths themselves, with peers, neighbours, and environment in general. Therefore, all blocks contribute to spread and transmission of STIs/RTIs, HIV/AIDS to youths.

Youths in HLIs and NVYs suffers from risk sexually behaviors which are contributed much by imitated modernization. Males and females play sexuality acts freely without any shame and sometimes live as husband and wife while they are not. Findings in this study revealed that female youths were the highest suffer of STIs, RTIs and HIV/AIDS than males. Among the pointed reasons include biological nature of female and the sexual maturation more active in female than males (WHO, 2016). This means that female youths at certain age they are derived more hormonal changes which attract them in sexual relationship with males than in males. This behavior has lead young females to become mothers before their age. They get children while they are still children too. They get unplanned pregnancies, single parent children because of having multiple partners, they get scissor birth, ectopic pregnancies, and risks and complicated reproductive health. Chalamilla et al. (2016) noticed that, youths in Tanzania are at increased risks of acquiring STIs which can facilitate HIV transmission.

The current results revealed that more than half of the respondents had adequate knowledge on STIs and RTIs infections but with more awareness of HIV infections. Lack of knowledge and understanding on STIs/RTIs infections contribute to activeness of youths in practicing bared sexual intercourse. Recent reports shows that in Africa in particular Tanzania adolescents and youths engage in unsafe sexual behavior which predisposes them to adverse outcome including sexually transmitted infections (Abdul et al. 2018; Chalamilla et al. 2016). In this study respondents mentioned some symptoms they experienced such as genital ulcer, painful urination, genital discharge, swelling, urinated blood but they were unable to tell if that were STIs infections Numerous studies have shown that STIs in particular HPV is associated with dangerous cervical cancer which has cause more mortality of females at tender age (WHO, 2016). Sexual intercourse currently has become the common practice among young people to the extent of boring parents. In Tanzania there is limited recent evidence on the risk outcomes to youths who practice much in sexual intercourse. May be these could 
have built awareness to young people to make them take care of their health's. Experience shows that in Tanzania sufficient knowledge and expertise about HIV/AIDS have been given to youths and therefore they are more familiar but limited information on STIs/RTIS are given to pregnant females who attend clinic for pregnancy cases. Majority remain without understanding of these aspect.

Through focus group discussion respondents contended that when they experienced pains of their genitor organs they used to buy antibiotics from pharmacy and use to cure the infections. Some noticed that it is shamed to go to hospital or dispensary to complain of sexual transmitted infections. Their response comply with (USAID, 2010 and WHO, 2016) reports that youths do not test their health for sexual transmitted infections as a result they attend while they are in severe condition. This problem might be contributed to lack of knowledge on the resulted outcome after being infected seriously. More findings in this study shows that youths engage in multiple partners which is among the factors for increased spread of STIs/RTIs and HIV infections. This finding agree with by Abdul et al. (2018) who noticed that youth between 15-24 years in Tanzania interact sexually with unsafe sexual intercourse. Yet STIs prevalence and sexual risk behaviours are high among youths and knowledge among them on STIs/RTIs are limited.

Accurate information to youths about their sexually health behaviour and outcomes are important and essential to improve their understanding about STIs such as Chlamydia trichomatic, Neisseria gonorrhoea, Human papillomavirus (HPV), Syphilis, Trichomonas vaginalis, Herpes which all are dangerous. The outcomes to these infections such as infertility, high risk to HIV attack, profound effects on the lives of children, ectopic pregnancies, cervical cancer, premature mortality and reproductive complications should be well known by youths to alert them to take care with their sexual behaviour. WHO/UNAIDS (2021) pointed on the same idea that youths in the period of adolescents are sexually active but they lack knowledge and understanding of symptoms of STIs/RTIs infections to the extent of getting risk health problems.

\section{CONCLUSION AND RECOMMENDATIONS}

The findings indicates that love affairs in higher learning institutions and neighbor village youths are among the acute contributing factors of transmitted and spread of STIs, RTIs and HIV/AIDS infections. This implies that in the coming years there will be more STIs/RTIs/HIV/AIDS and more children resulted from parents' unprotected sexual activity. Therefore, it is imperative to establish sensitization programs for educating youths about STIs/RTIs/HIV/AIDs and resulted risks. There are still many risky sexual behaviours common to youths which put them in danger of getting STIs and RTIs. This study recommend on the establishment of partnership programs with community organizations, higher learning institutions management, health service providers, policy makers and public agents so that together co-operate to promote the use of best practices policy in educating youths and employ proper systems that show the greatest promise of supporting genuine reproductive healthy youth development interventions.

\section{REFERENCES}

[1] Abdul, R; Gerritsen, A.A.M; Mwangoma, N \& Geubbel, E. (2018). Prevalence on self-reported symptoms of sexually transmitted infections, anowledge behavior.https:/doi.org/10.1186/s12879-018-3138-1

[2] G; Mbwana, J; Mhalu, F; Mmari, E; Majigo, M; Swai, A; Urassa, W and Sandstrom, E. (2016). Patterns of sexually transmitted infections in adolescents and youths in Dar es Salaam, Tanzania. Doi: $10.1186 / 1471-2334-6-22$

[3] Cheng, I. (2018). Sexuality education in Taiwan. Research Office Information Services: Division Legislative Council Secretariet. http://homepage.ntu.edu.tw/ntuidrec/file/20180913/4

[4] Fenton, K.A; Johnson, A. M; McManus, S \& Erens, B. (2021). Measuring sexual behavior: Methodological challenges in survey research. Vol. 4, 77; 84-92. http://sti.bmj.com/Nov. 6, 2021.

[5] Gosselin, K; Roman, J \& Bunuan, R. (2010). The theory of 'Possible-selves'. https://doi.org/10.1016/j.tate.2010.02.005

[6] Kristin, D.T; Rena, L; Claire, D; Brindis, D \& Philip, R. L. (2011). Improving the health of youth: A guide for state-level strategic planning and action. National Adolescent Health Information and Innovation Center, University of Califonia, San Francisco.

[7] Madeni, F; Horiuchi, S \& Lida, M. (2011). Evaluation of reproductive health awareness program for adolescence in urban Tanzania-A quasi-experimental pre-test post-test research. http:///www.reproductive-health-journal.com/content/8/1/21

[8] Ministry of health and social welfare, MHSOW, Tanzania (2018). National Guidelines for management of sexually transmitted and reproductive tract infections

[9] USAID (2010). Tanzania service delivery guidelines for cervical cancer prevention and control. Dar es Salaam, Tanzania.

[10] Wekesh, F.M; Nyakangi, V; Njagi, J \& Bangha, M. (2019). Comprehensive sexuality education in Sub-Saharan Africa. Forum for African Women Educationalists. African Population and Health Research Center (APHRC). Nairobi, Kenya.

[11] World Health Organization (WHO) (2016). Global health-sector strategy on: Sexually transmitted infections 2016-2021. Towards ending STIs. Department of Reproductive Health and Research.

[12] WHO/UNAIDS (2021). Sexually transmitted diseases: Policies and principles for prevention and care. 